\title{
Pengaruh Jumlah dan Diameter Helix terhadap Daya Dukung Fondasi Helical Pile
}

\author{
SENA BAYU ADJI FITRIANA, INDRA NOER HAMDHAN \\ Jurusan Teknik Sipil, Institut Teknologi Nasional, Bandung \\ Email: sena.fitriana@yahoo.com
}

\begin{abstract}
ABSTRAK
Fondasi helical pile adalah fondasi tiang baja yang memiliki helix untuk menambah daya dukung yang dihasilkan. Ada beberapa hal yang dapat dilakukan untuk menentukan kapasitas daya dukung fondasi helical pile seperti, membandingkan metode analitis yang terdiri dari metode cylindrical shear dan metode individual bearing dengan metode elemen hingga. Banyak variasi yang dapat dilakukan untuk meningkatkan daya dukung fondasi helical pile, variasi yang dilakukan untuk mengetahui kapasitas daya dukung fondasi ini seperti menambah jumlah helix dan memvariasikan diameter helix pada helical pile. Hasil perhitungan kapasitas daya dukung akibat bertambahnya jumlah helix menunjukan penambahan sebesar 9,38\% pada tanah lempung dan 5,58\% pada tanah pasir dan adanya penambahan ukuran diameter tengah sebesar 50\% menambah daya dukung sebesar 19,66\% pada tanah lempung dan $10,83 \%$ pada tanah pasir.
\end{abstract}

Kata kunci: helical pile, cylindrical shear, individual bearing, elemen hingga

\begin{abstract}
Helical pile foundation is a steel pile that has a helix to increase the bearing capacity. There are several things that can be done to determine the bearing capacity of helical pile such as, comparing analytical methods (cylindrical shear and individual bearing) with finite element method. Many variations can be done to increase the bearing capacity of the helical pile foundation, variations were made to determine the bearing capacity such as increasing the number of helix and increasing the diameter helix on the helical pile. The result of the bearing capacity due to increasing the number of helix shows the addition of $9.38 \%$ in the clay soil and $5.58 \%$ in the sand soil. By adding $20 \mathrm{~cm}$ diameter size of helix, it also increases the bearing capacity $19.66 \%$ in clay soil and $10.83 \%$ in sand soil.
\end{abstract}

Keywords: helical pile, cylindrical shear, individual bearing, finite element 


\section{PENDAHULUAN}

Fondasi merupakan pekerjaan yang paling utama dalam suatu proyek konstruksi. Semua bangunan selalu bertumpu pada tanah dan harus didukung oleh suatu fondasi. Fondasi adalah suatu bagian struktur bawah yang berfungsi menyalurkan beban-beban yang bekerja dari struktur atas (upper structure) ke lapisan tanah keras. Untuk itu, suatu fondasi harus diperhitungkan agar dapat menjaga kesetabilan, menahan beban-beban yang bekerja dari struktur bagian atas. Salah satu jenis alternatif fondasi yang dapat digunakan pada proyek konstruksi adalah fondasi helical pile. Fondasi helical pile umumnya merupakan fondasi bermaterial baja yang memiliki helix pada bagian ujung atau beberapa helix pada satu tiang fondasi. Fondasi helical pile umumnya banyak digunakan pada bangunan tower dan khususnya pada bangunan yang menghasilkan gaya axia/tarik. Di Indonesia fondasi jenis ini masih sangat jarang digunakan, padahal banyak sekali keuntungan menggunakan fondasi helical pile seperti proses pemasangan tiang helical dapat dikerjakan pada berbagai kondisi cuaca, bersahabat dengan lingkungan, proses instalasi yang relatif lebih cepat, tidak menyebabkan kebisingan, tidak ada getaran, dapat dilepas dan dipindahkan, mudah untuk disambung dan dapat digunakan untuk memperbaiki bahkan menambah daya dukung fondasi pada struktur yang sudah ada. Banyak sekali variasi jumlah ataupun diameter helix yang dapat digunakan pada satu tiang fondasi. Hal ini bertujuan agar fondasi tersebut dapat mendukung struktur diatasnya. Pemilihan jumlah helix dan diameter juga bergantung pada seberapa besar beban yang diterima fondasi tersebut. Selain beban, faktor dari jenis struktur yang ada juga dapat mempengaruhi ukuran dan jumlah helix.

\section{TINJAUAN PUSTAKA}

\subsection{Fondasi Helical Pile}

Fondasi tiang berulir (helical pile) adalah fondasi tiang baja yang memiliki beberapa ulir (helix) dalam satu tiang dimana helix berfungsi untuk menambah daya dukung fondasi tiang. Fondasi jenis ini biasa digunakan pada struktur Menara (tower) dan mercusuar.

\subsection{Kapasitas Daya Dukung Ujung $\left(Q_{b}\right)$}

Kapasitas daya dukung ujung $\left(Q_{b}\right)$ adalah kapasitas yang dihasilkan oleh tahanan ujung helix fondasi. Untuk mencari nilai daya dukung ujung $\left(Q_{b}\right)$ dapat digunakan Persamaan 1 pada jenis tanah pasir dan Persamaan $\mathbf{2}$ pada jenis tanah lempung.

$$
\begin{gathered}
Q_{b}=N_{q} \cdot \gamma^{\prime} \cdot H \cdot \frac{\pi\left(D_{h}{ }^{2}-d^{2}\right)}{4} \\
Q_{b}=\frac{\pi\left(D_{h}{ }^{2}-d^{2}\right)}{4} \cdot N_{c} \cdot C_{u}+\gamma^{\prime} \cdot H
\end{gathered}
$$

halmana:

$N_{q} \quad=$ faktor kapasitas bearing untuk tanah pasir,

$\gamma^{\prime}=$ berat volume tanah $\left[\mathrm{kN} / \mathrm{m}^{3}\right]$,

$H \quad=$ kedalaman helix di bawah permukaan tanah [m],

$D_{h} \quad=$ diameter helix [m],

$d \quad=$ diameter poros tiang $[\mathrm{m}]$,

$N_{c} \quad=$ faktor kapasitas bearing untuk tanah lempung,

$C_{u} \quad=$ kuat geser undrained tanah lempung [kPa]. 
Menurut CFEM (2006) dalam Aryanata (2015), nilai $N_{c}$ pada jenis tanah lempung diambil 9,0 sedangkan nilai $N_{q}$ pada tanah pasir direkomendasikan menggunakan metode Vesic (1963) seperti pada Tabel 1 berikut.

Tabel 1. Bearing Capacity Factor

\begin{tabular}{cccccccc}
$\phi\left[^{\circ}\right]$ & $\boldsymbol{N}_{\boldsymbol{c}}$ & $\boldsymbol{N}_{\boldsymbol{q}}$ & $\boldsymbol{N}_{\boldsymbol{\gamma}}$ & $\left.\boldsymbol{\phi} \mathbf{[}^{\circ}\right]^{\circ}$ & $\boldsymbol{N}_{\boldsymbol{c}}$ & $\boldsymbol{N}_{\boldsymbol{q}}$ & $\boldsymbol{N}_{\boldsymbol{\gamma}}$ \\
\hline 0 & 5,14 & 1,00 & 0,00 & 23 & 18,05 & 8,66 & 8,20 \\
\hline 1 & 5,38 & 1,09 & 0,07 & 24 & 19,32 & 9,60 & 9,44 \\
\hline 2 & 5,63 & 1,20 & 0,15 & 25 & 20,72 & 10,66 & 10,88 \\
\hline 3 & 5,90 & 1,31 & 0,24 & 26 & 22,25 & 11,85 & 12,54 \\
\hline 4 & 6,19 & 1,43 & 0,34 & 27 & 23,94 & 13,20 & 14,47 \\
\hline 5 & 6,49 & 1,57 & 0,45 & 28 & 25,80 & 14,72 & 16,72 \\
\hline 6 & 6,81 & 1,72 & 0,57 & 29 & 27,86 & 16,44 & 19,34 \\
\hline 7 & 7,16 & 1,88 & 0,71 & 30 & 30,14 & 18,40 & 22,40 \\
\hline 8 & 7,53 & 2,06 & 0,86 & 31 & 32,67 & 20,63 & 25,99 \\
\hline 9 & 7,92 & 2,25 & 1,03 & 32 & 35,49 & 23,18 & 30,22 \\
\hline 10 & 8,35 & 2,47 & 1,22 & 33 & 38,64 & 26,09 & 35,19 \\
\hline 11 & 8,80 & 2,71 & 1,44 & 34 & 42,16 & 29,44 & 41,06 \\
\hline 12 & 9,28 & 2,97 & 1,69 & 35 & 46,12 & 33,30 & 48,03 \\
\hline 13 & 9,81 & 3,26 & 1,97 & 36 & 50,59 & 37,75 & 56,31 \\
\hline 14 & 10,37 & 3,59 & 2,29 & 37 & 55,63 & 42,92 & 66,19 \\
\hline 15 & 10,98 & 3,94 & 2,65 & 38 & 61,35 & 48,93 & 78,03 \\
\hline 16 & 11,63 & 4,34 & 3,06 & 39 & 67,87 & 55,96 & 92,25 \\
\hline 17 & 12,34 & 4,77 & 3,53 & 40 & 75,31 & 64,20 & 109,41 \\
\hline 18 & 13,10 & 5,26 & 4,07 & 41 & 83,86 & 73,90 & 130,22 \\
\hline 19 & 13,93 & 5,80 & 4,68 & 42 & 93,71 & 85,38 & 155,55 \\
\hline 20 & 14,83 & 6,40 & 5,39 & 43 & 105,11 & 99,02 & 186,54 \\
\hline 21 & 15,82 & 7,07 & 6,20 & 44 & 118,37 & 115,31 & 224,64 \\
\hline 22 & 16,88 & 7,82 & 7,13 & 45 & 133,88 & 134,88 & 271,76 \\
\hline
\end{tabular}

(Sumber: Vesic, 1963 dalam Barbour et al, 2006)

\subsection{Kapasitas Daya Dukung Selimut Tiang $\left(Q_{s}\right)$}

Kapasitas daya dukung selimut tiang $\left(Q_{S}\right)$ adalah tahanan yang dihasilkan oleh gesekan antara selimut tiang dengan tanah. Pada perhitungan kapasitas daya dukung selimut tiang, nilai jarak antara helix dapat mempengaruhi besarnya nilai daya dukung selimut tiang. Untuk menghitung kapasitas daya dukung selimut tiang $\left(Q_{S}\right)$ pada tanah pasir dapat menggunakan Persamaan 3.

$$
Q_{s}=\pi \cdot d \cdot H_{e f f} \cdot\left(\frac{1}{2} \cdot \gamma^{\prime} \cdot H_{1} \cdot K_{s} \cdot \tan \phi\right)
$$

halmana:

$K_{S} \quad=$ koefisien tekanan tanah lateral dalam tekan,

$\phi \quad=$ sudut geser $\operatorname{tanah}\left[{ }^{\circ}\right]$. 
Dimana $\mathrm{H}_{\text {eff }}$ dapat dinyatakan dengan Persamaan 4 dibawah ini:

$$
H_{e f f}=H_{1}-D_{h}
$$

$H_{1} \quad=$ kedalaman helix paling atas [m],

$D_{h} \quad=$ diameter helix $[\mathrm{m}]$.

Dalam menentukan nilai $K_{u}$, Mitsch and Clemence (1985) dalam Aryanata (2015) merekomendasikan nilai $K_{u}$ berdasarkan nilai sudut geser tanah seperti yang ditujukan pada Tabel 2 dibawah ini:

Tabel 2. Rekomendasi Nilai $K_{u}$

\begin{tabular}{cc} 
Sudut Geser Tanah $(\boldsymbol{\phi})$ & Koefisien Tarik $\left(\boldsymbol{K}_{\boldsymbol{u}}\right)$ \\
\hline $25^{\circ}$ & 0,70 \\
\hline $30^{\circ}$ & 0,90 \\
\hline $35^{\circ}$ & 1,50 \\
\hline $40^{\circ}$ & 2,35 \\
\hline $45^{\circ}$ & 3,20 \\
\hline
\end{tabular}

(Sumber: Mitsch and Clemence, 1985 dalam Aryanata, 2015)

Untuk menghitung nilai koefisien tekan $\left(K_{S}\right)$ dapat menggunakan Persamaan 5

$$
K_{S}=\frac{\beta}{\tan \delta}
$$

halmana:

$\beta=$ parameter desain gesekan selimut tiang untuk perpindahan tiang di pasir Tabel $\mathbf{3}$ (CFEM, 2006 dalam Aryanata, 2015),

$\delta \quad=$ sudut geser antara tiang dan tanah, sama dengan $0,6 \phi$ untuk tiang baja di pasir (Kulhawy, 1984 dalam Aryanata, 2015).

Tabel 3. Parameter Koefisien $\beta$

\begin{tabular}{cc}
\hline Soil Type & Driven Pile \\
\hline Silt & $0,3-0,5$ \\
\hline Loose sand & $0,3-0,8$ \\
\hline Medium sand & $0,6-1,0$ \\
\hline Dense sand & $0,8-1,2$ \\
\hline Gravel & $0,8-1,5$ \\
\hline
\end{tabular}

(Sumber: CFEM, 2006 dalam Aryanata, 2015)

Sedangkan untuk menghitung kapasitas daya dukung selimut tiang pada tanah lempung dapat menggunakan Persamaan 6.

$$
Q_{s}=\pi \cdot d \cdot H_{e f f} \cdot C_{u} \cdot \alpha
$$

halmana:

$d \quad=$ diameter poros tiang $[\mathrm{m}]$, 


$$
\begin{array}{ll}
H_{\text {eff }} & =H_{1}-D_{h}[\mathrm{~m}] \\
C_{u} & =\text { kuat geser undrained tanah lempung [kPa] } \\
\alpha & =\text { faktor adhesi. }
\end{array}
$$

Pada tanah lempung, nilai faktor adhesi dapat ditentukan menggunakan grafik yang tertera pada Gambar 1.

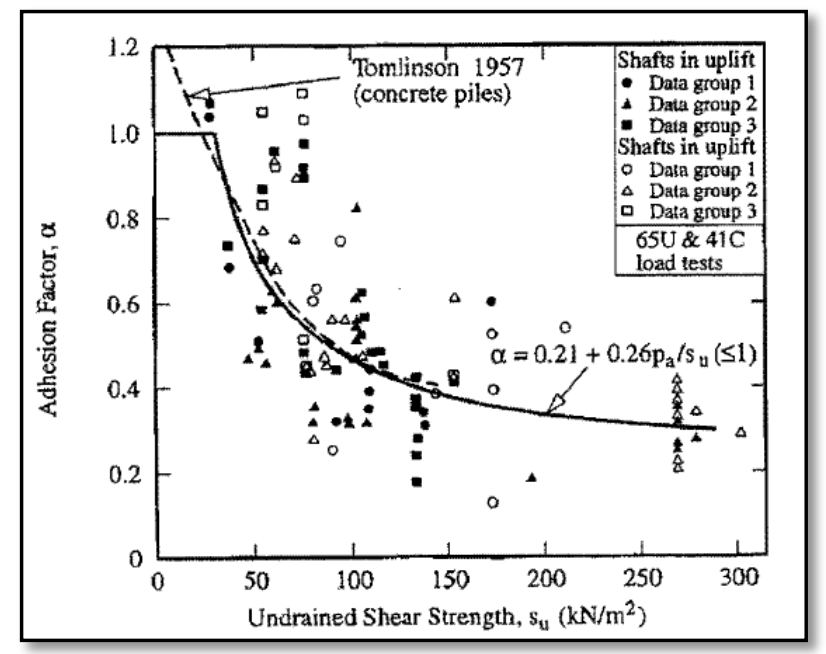

Gambar 1. Adhesion factor for driven piles in clay (Sumber: Barbour et al, 2006)

\subsection{Kapasitas Daya Dukung Silinder $\left(Q_{c}\right)$}

Kapasitas daya dukung silinder adalah tahanan yang dihasilkan oleh setiap helix pada satu tiang helical pile. Tahanan yang dihasilkan dari helix dianggap menerus mulai dari helix paling atas menuju helix bawah. Untuk menghitung nilai daya dukung silinder dapat menggunakan Persamaan 7 untuk jenis tanah pasir dan Persamaan 8 untuk jenis tanah lempung.

$$
\begin{gathered}
Q_{c}=\pi \cdot D_{h} \cdot \frac{1}{2} \cdot \gamma^{\prime} \cdot K_{s} \cdot \tan \emptyset \cdot\left(H_{n}{ }^{2}-H_{1}{ }^{2}\right) \\
Q_{c}=\pi \cdot D_{h} \cdot C_{u} \cdot \alpha \cdot\left(H_{n}-H_{1}\right)
\end{gathered}
$$

halmana:

$H_{n} \quad=$ kedalaman helix paling bawah [m],

$H_{1} \quad=$ kedalaman helix paling atas [m].

\subsection{Metode Individual Bearing}

Metode individual bearing mengasumsikan bahwa pada setiap pelat helix memiliki daya dukung ujung dan menurut CFEM (2006) dalam Aryanata (2015) metode ini biasanya digunakan jika pile memiliki rasio jarak $\left(\frac{S}{D_{h}} \geq 3\right)$. Untuk menentukan kapasitas daya dukung ultimate $\left(Q_{\text {ult }}\right)$ menggunakan metode individual bearing dapat dilakukan dari penjumlahan daya dukung ujung $\left(Q_{b}\right)$ dari setiap helix ditambah dengan kapasitas daya dukung selimut tiang $\left(Q_{S}\right)$ seperti pada Persamaan 9.

$$
Q_{u l t}=Q_{b}+Q_{s}
$$


Dimana nilai $Q_{b}$ didapatkan dari penjumlahan daya dukung ujung dari setiap helix yang biasanya dinyatakan dengan $Q_{b 1}, Q_{b 2}, Q_{b n}$ sesuai dengan jumlah helix yang ada, sehingga persamaan untuk mencari daya dukung ultimate seperti pada Persamaan 10.

$$
Q_{u l t}=Q_{b 1}+Q_{b 2}+Q_{b n}+Q_{s}
$$

\subsection{Metode Cylindrical Shear}

Metode cylindrical shear adalah metode yang mengasumsikan helix paling atas sampai dengan helix yang paling bawah sebagai daya dukung silinder dan menurut CFEM (2006) dalam Aryanata (2015), metode ini biasanya digunakan jika pile memiliki rasio jara $\left(\frac{S}{D_{h}}<3\right)$. Untuk menghitung kapasitas daya dukung ultimate $\left(Q_{u l t}\right)$ menggunakan Metode cylindrical shear dapat dilakukan dari penjumlahan kapasitas daya dukung ujung $\left(Q_{b}\right)$ ditambah dengan kapasitas daya dukung selimut tiang $\left(Q_{s}\right)$ ditambah kapasitas daya dukung silinder $\left(Q_{c}\right)$ seperti pada Persamaan 11 di bawah ini.

$$
Q_{u l t}=Q_{b}+Q_{s}+Q_{c}
$$

\subsection{Metode Elemen Hingga}

Metode Elemen Hingga adalah suatu metode numerik yang bertujuan untuk memperoleh suatu pendekatan dari suatu persamaan diferensial parsial. Untuk menggunakan metode ini dibutuhkan perangkat lunak dalam proses perhitungannya. Perangkat lunak yang digunakan adalah PLAXIS.

\section{METODE PENELITIAN}

\subsection{Metode Penelitian}

Metode penelitian tergambar pada Gambar $\mathbf{2}$ di bawah ini.

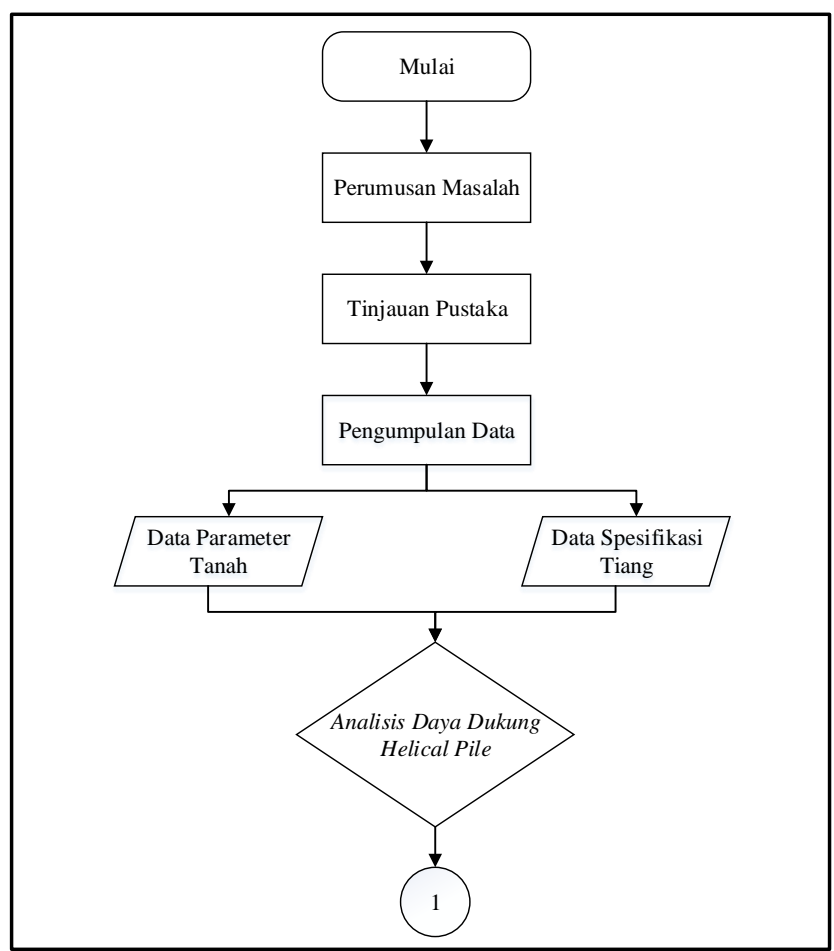

Gambar 2. Bagan alir penelitian 


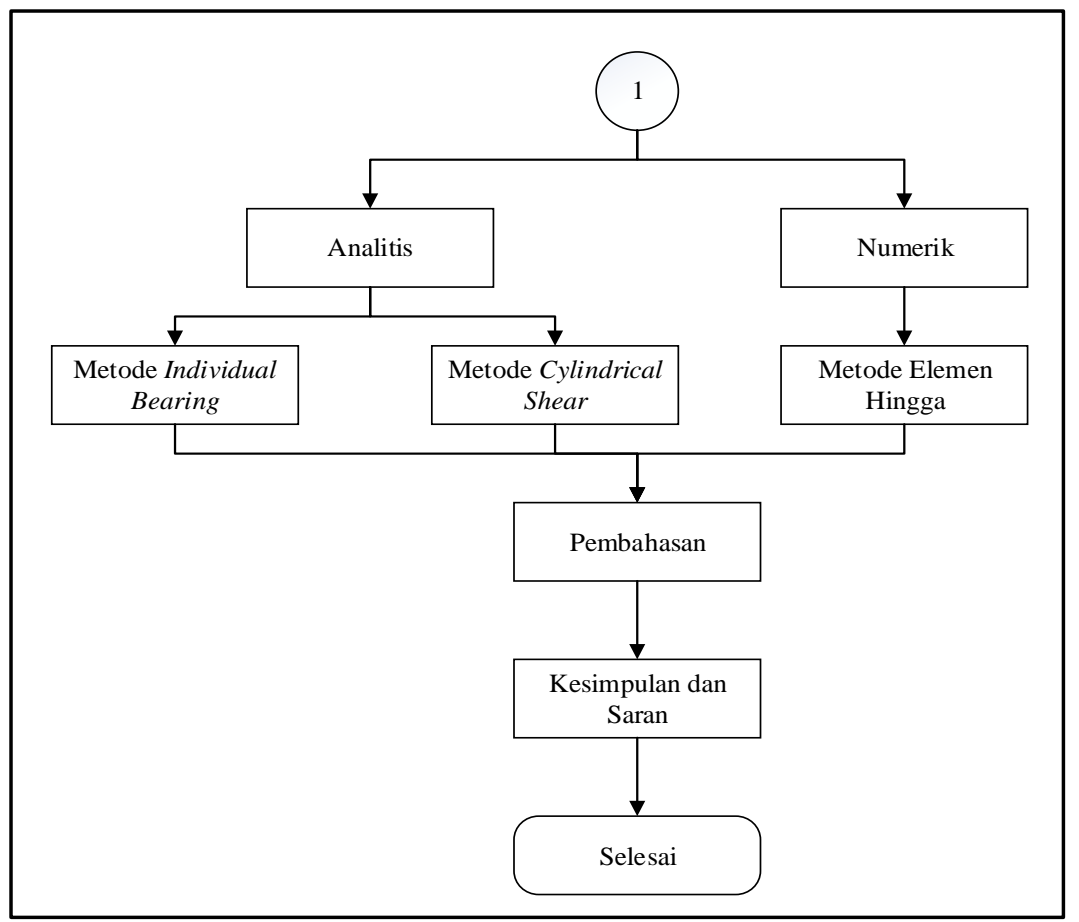

Gambar 2. Bagan alir penelitian (lanjutan)

\subsection{Pengumpulan Data}

Data parameter tanah pasir dan lempung diasumsikan seperti pada Tabel $\mathbf{4}$ dan data spesifikasi tiang helicalyang digunakan seperti pada Tabel $\mathbf{5}$.

Tabel 4. Data Parameter Tanah

\begin{tabular}{ccc}
\hline \multirow{2}{*}{ Data Tanah } & \multicolumn{3}{c}{ Jenis Tanah } \\
\cline { 2 - 3 } & Pasir & Lempung \\
\hline$\gamma_{\text {unsat }}\left[\mathrm{KN} / \mathrm{m}^{3}\right]$ & 17 & 16 \\
\hline $\boldsymbol{\gamma}_{\text {sat }}\left[\mathrm{KN} / \mathrm{m}^{3}\right]$ & 20 & 18 \\
\hline $\boldsymbol{v}$ & 0,2 & 0,15 \\
\hline $\boldsymbol{C u}\left[\mathrm{KN} / \mathrm{m}^{2}\right]$ & 1 & 35 \\
\hline $\boldsymbol{\phi}\left[{ }^{\circ}\right]$ & 35 & 25 \\
\hline $\boldsymbol{\psi}\left[^{\circ}\right]$ & 2 & 0
\end{tabular}

(Sumber : PLAXIS 2D Reference Manual, 2016)

Tabel 5. Data Spesifikasi Tiang Helical

\begin{tabular}{ccccccc}
$\begin{array}{c}\text { No. } \\
\text { Tiang }\end{array}$ & $\boldsymbol{H}[\mathbf{m}]$ & $\boldsymbol{H}_{\mathbf{1}}[\mathbf{m}]$ & $\begin{array}{c}\text { D Helix } \\
\text { Setiap } \\
\text { Ujung }[\mathbf{m}]\end{array}$ & $\begin{array}{c}\text { D Helix } \\
\text { Tengah } \\
{[\mathbf{m}]}\end{array}$ & $\begin{array}{c}\text { D } \\
\text { Shaft } \\
{[\mathbf{m}]}\end{array}$ & $\begin{array}{c}\boldsymbol{n} \\
\text { Helix }\end{array}$ \\
\hline 1 & 5 & 2 & 0,4 & - & 0,1 & 2 \\
\hline 2 & 5 & 2 & 0,4 & 0,4 & 0,1 & 3 \\
\hline 3 & 5 & 2 & 0,4 & 0,4 & 0,1 & 4 \\
\hline 4 & 5 & 2 & 0,4 & 0,4 & 0,1 & 5 \\
\hline 5 & 5 & 2 & 0,4 & 0,6 & 0,1 & 3 \\
\hline 6 & 5 & 2 & 0,4 & 0,6 & 0,1 & 4 \\
\hline 7 & 5 & 2 & 0,4 & 0,6 & 0,1 & 5 \\
\hline
\end{tabular}




\section{HASIL PENELITIAN DAN PEMBAHASAN}

\subsection{Hasil Penelitian}

Hasil perhitungan nilai daya dukung ultimate dengan menggunakan metode cylindrical shear pada tanah lempung dapat dilihat pada Tabel $\mathbf{6}$ dan pada tanah pasir pada Tabel 7.

Tabel 6. Data Kapasitas Ultimate Metode Cylindrical Shear pada Tanah Lempung

\begin{tabular}{cccccccc}
$\begin{array}{c}\text { No. } \\
\text { Tiang }\end{array}$ & $\begin{array}{c}\boldsymbol{D} \text { Helix } \\
\text { Setiap } \\
\text { Ujung } \\
{[\mathbf{m}]}\end{array}$ & $\begin{array}{c}\boldsymbol{D} \text { Helix } \\
\text { Tengah } \\
{[\mathbf{m}]}\end{array}$ & $\begin{array}{c}\boldsymbol{n} \\
\text { Helix }\end{array}$ & $\begin{array}{c}\boldsymbol{Q}_{\boldsymbol{b} \mathbf{1}} \\
{[\mathbf{k N}]}\end{array}$ & $\begin{array}{c}\boldsymbol{Q}_{\boldsymbol{s}} \\
{[\mathbf{k N}]}\end{array}$ & $\begin{array}{c}\boldsymbol{Q}_{\boldsymbol{c}} \\
{[\mathbf{k N}]}\end{array}$ & $\begin{array}{c}\boldsymbol{Q}_{u l t} \\
{[\mathbf{k N}]}\end{array}$ \\
\hline 1 & 0,4 & 0,4 & 2 & 49,612 & 17,584 & 131,880 & 199,076 \\
\hline 2 & 0,4 & 0,4 & 3 & 49,612 & 17,584 & 131,880 & 199,076 \\
\hline 3 & 0,4 & 0,4 & 4 & 49,612 & 17,584 & 131,880 & 199,076 \\
\hline 4 & 0,4 & 0,4 & 5 & 49,612 & 17,584 & 131,880 & 199,076 \\
\hline 5 & 0,4 & 0,6 & 3 & 49,612 & 17,584 & 197,820 & 265,016 \\
\hline 6 & 0,4 & 0,6 & 4 & 49,612 & 17,584 & 197,820 & 265,016 \\
\hline 7 & 0,4 & 0,6 & 5 & 49,612 & 17,584 & 197,820 & 265,016 \\
\hline
\end{tabular}

Tabel 7. Data Kapasitas Ultimate Metode Cylindrical Shear pada Tanah Pasir

\begin{tabular}{cccccccc}
$\begin{array}{c}\text { No. } \\
\text { Tiang }\end{array}$ & $\begin{array}{c}\boldsymbol{D} \text { Helix } \\
\text { Setiap } \\
\text { Ujung } \\
{[\mathbf{m}]}\end{array}$ & $\begin{array}{c}\boldsymbol{D} \text { Helix } \\
\text { Tengah } \\
{[\mathbf{m}]}\end{array}$ & $\begin{array}{c}\boldsymbol{n} \\
\text { Helix }\end{array}$ & $\begin{array}{c}\boldsymbol{Q}_{\boldsymbol{b} \mathbf{1}} \\
{[\mathbf{k N}]}\end{array}$ & $\begin{array}{c}\boldsymbol{Q}_{\boldsymbol{s}} \\
{[\mathbf{k N}]}\end{array}$ & $\begin{array}{c}\boldsymbol{Q}_{\boldsymbol{c}} \\
{[\mathbf{k N}]}\end{array}$ & $\begin{array}{c}\boldsymbol{Q}_{\text {ult }} \\
{[\mathbf{k N}]}\end{array}$ \\
\hline 1 & 0,4 & 0,4 & 2 & 355,510 & 9,340 & 245,290 & 610,150 \\
\hline 2 & 0,4 & 0,4 & 3 & 355,510 & 9,340 & 245,290 & 610,150 \\
\hline 3 & 0,4 & 0,4 & 4 & 355,510 & 9,340 & 245,290 & 610,150 \\
\hline 4 & 0,4 & 0,4 & 5 & 355,510 & 9,340 & 245,290 & 610,150 \\
\hline 5 & 0,4 & 0,6 & 3 & 355,510 & 9,340 & 367,940 & 732,790 \\
\hline 6 & 0,4 & 0,6 & 4 & 355,510 & 9,340 & 367,940 & 732,790 \\
\hline 7 & 0,4 & 0,6 & 5 & 355,510 & 9,340 & 367,940 & 732,790 \\
\hline
\end{tabular}

Hasil perhitungan nilai daya dukung ultimate dengan menggunakan metode individual bearing pada tanah lempung dapat dilihat pada Tabel 8 dan pada tanah pasir pada Tabel 9.

Tabel 8. Data Kapasitas Ultimate Metode Individual Bearing pada Tanah Lempung

\begin{tabular}{ccccccccc}
$\begin{array}{c}\text { No. } \\
\text { Tiang }\end{array}$ & $\begin{array}{c}\text { Helix } \\
\text { Setiap } \\
\text { Ujung } \\
{[\mathbf{m}]}\end{array}$ & $\begin{array}{c}\boldsymbol{D} \text { Helix } \\
\text { Tengah } \\
{[\mathbf{m}]}\end{array}$ & $\begin{array}{c}n \\
\text { Helix }\end{array}$ & $\begin{array}{c}\boldsymbol{Q}_{\boldsymbol{b} 1} \\
{[\mathbf{k N}]}\end{array}$ & $\begin{array}{c}\boldsymbol{Q}_{\boldsymbol{b} 2} \\
{[\mathbf{k N}]}\end{array}$ & $\begin{array}{c}\boldsymbol{Q}_{\boldsymbol{b} 3} \\
{[\mathbf{k N}]}\end{array}$ & $\begin{array}{c}\boldsymbol{Q}_{\boldsymbol{s}} \\
{[\mathbf{k N}]}\end{array}$ & $\begin{array}{c}\boldsymbol{Q}_{u l t} \\
{[\mathbf{k N}]}\end{array}$ \\
\hline 1 & 0,4 & 0,4 & 2 & 49,612 & 46,511 & - & 17,584 & 113,707 \\
\hline 2 & 0,4 & 0,4 & 3 & 49,612 & 46,511 & 46,511 & 17,584 & 160,218 \\
\hline 3 & 0,4 & 0,4 & 4 & 49,612 & 46,511 & 46,511 & 17,584 & 206,729 \\
\hline 4 & 0,4 & 0,4 & 5 & 49,612 & 46,511 & 46,511 & 17,584 & 253,241 \\
\hline 5 & 0,4 & 0,6 & 3 & 49,612 & 46,511 & 108,526 & 17,584 & 222,233 \\
\hline
\end{tabular}


Tabel 8. Data Kapasitas Ultimate Metode Individual Bearing pada Tanah Lempung lanjutan

\begin{tabular}{|c|c|c|c|c|c|c|c|c|}
\hline $\begin{array}{l}\text { No. } \\
\text { Tiang }\end{array}$ & $\begin{array}{c}D \\
\text { Helix } \\
\text { Setiap } \\
\text { Ujung } \\
{[\mathrm{m}]}\end{array}$ & $\begin{array}{c}\text { D Helix } \\
\text { Tengah } \\
{[\mathrm{m}]}\end{array}$ & $\begin{array}{c}n \\
\text { Helix }\end{array}$ & $\begin{array}{c}Q_{b 1} \\
{[k N]}\end{array}$ & $\begin{array}{c}Q_{b 2} \\
{[\mathrm{kN}]}\end{array}$ & $\begin{array}{c}Q_{b 3} \\
{[\mathbf{k N}]}\end{array}$ & $\begin{array}{c}Q_{s} \\
{[\mathbf{k N}]}\end{array}$ & $\begin{array}{c}Q_{\text {ult }} \\
\text { [kN] }\end{array}$ \\
\hline 6 & 0,4 & 0,6 & 4 & 49,612 & 46,511 & 108,526 & 17,584 & 330,759 \\
\hline 7 & 0,4 & 0,6 & 5 & 49,612 & 46,511 & 108,526 & 17,584 & 439,286 \\
\hline
\end{tabular}

Tabel 9. Data Kapasitas Ultimate Metode Individual Bearing pada Tanah Pasir

\begin{tabular}{|c|c|c|c|c|c|c|c|c|}
\hline $\begin{array}{l}\text { No. } \\
\text { Tiang }\end{array}$ & $\begin{array}{c}D \\
\text { Helix } \\
\text { Setiap } \\
\text { Ujung } \\
{[\mathrm{m}]}\end{array}$ & $\begin{array}{c}\text { D Helix } \\
\text { Tengah } \\
{[\mathrm{m}]}\end{array}$ & $\begin{array}{c}n \\
\text { Helix }\end{array}$ & $\begin{array}{c}Q_{b 1} \\
{[\mathbf{k N}]}\end{array}$ & $\begin{array}{c}Q_{b 2} \\
{[\mathbf{k N}]}\end{array}$ & $\begin{array}{c}Q_{b 3} \\
{[\mathrm{kN}]}\end{array}$ & $\begin{array}{c}Q_{s} \\
{[\mathbf{k N}]}\end{array}$ & $\begin{array}{c}Q_{\text {ult }} \\
\text { [kN] }\end{array}$ \\
\hline 1 & 0,4 & 0,4 & 2 & 355,511 & 333,291 & - & 9,344 & 698,147 \\
\hline 2 & 0,4 & 0,4 & 3 & 355,511 & 333,291 & 333,291 & 9,344 & $1.031,438$ \\
\hline 3 & 0,4 & 0,4 & 4 & 355,511 & 333,291 & 333,291 & 9,344 & $1.364,729$ \\
\hline 4 & 0,4 & 0,4 & 5 & 355,511 & 333,291 & 333,291 & 9,344 & $1.698,021$ \\
\hline 5 & 0,4 & 0,6 & 3 & 355,511 & 333,291 & 777,680 & 9,344 & $1.475,827$ \\
\hline 6 & 0,4 & 0,6 & 4 & 355,511 & 333,291 & 777,680 & 9,344 & $2.253,506$ \\
\hline 7 & 0,4 & 0,6 & 5 & 355,511 & 333,291 & 777,680 & 9,344 & $3.031,186$ \\
\hline
\end{tabular}

Hasil perhitungan nilai daya dukung ultimate dengan menggunakan metode elemen hingga pada tanah lempung dapat dilihat pada Tabel $\mathbf{1 0}$ dan pada tanah pasir pada Tabel $\mathbf{1 1 .}$

Tabel 10. Data Kapasitas Ultimate Metode Elemen Hingga pada Tanah Lempung

\begin{tabular}{ccccccc}
\hline $\begin{array}{c}\text { No. } \\
\text { Tiang }\end{array}$ & $\begin{array}{c}\text { D Helix } \\
\text { Setiap } \\
\text { Ujung } \\
{[\mathbf{m}]}\end{array}$ & $\begin{array}{c}\text { D Helix } \\
\text { Tengah } \\
{[\mathbf{m}]}\end{array}$ & $\begin{array}{c}\boldsymbol{n} \\
\text { Helix }\end{array}$ & $\begin{array}{c}\text { Beban } \\
{\left[\frac{\mathbf{k N}}{\mathbf{m}}\right]}\end{array}$ & $\begin{array}{c}\text { Luas } \\
\text { Area } \\
{\left[\mathbf{m}^{2}\right]}\end{array}$ & $\begin{array}{c}\boldsymbol{Q}_{\text {ult }} \\
{[\mathbf{k N}]}\end{array}$ \\
\hline 1 & 0,4 & 0,4 & 2 & 26.000 & 0,00785 & 203,439 \\
\hline 2 & 0,4 & 0,4 & 3 & 37.000 & 0,00785 & 268,054 \\
\hline 3 & 0,4 & 0,4 & 4 & 37.000 & 0,00785 & 277,409 \\
\hline 4 & 0,4 & 0,4 & 5 & 40.000 & 0,00785 & 279,280 \\
\hline 5 & 0,4 & 0,6 & 3 & 45.000 & 0,00785 & 323,181 \\
\hline 6 & 0,4 & 0,6 & 4 & 48.000 & 0,00785 & 351,864 \\
\hline 7 & 0,4 & 0,6 & 5 & 50.000 & 0,00785 & 352,528 \\
\hline
\end{tabular}


Tabel 11. Data Kapasitas Ultimate Metode Elemen Hingga pada Tanah Pasir

\begin{tabular}{ccccccc}
\hline $\begin{array}{c}\text { No. } \\
\text { Tiang }\end{array}$ & $\begin{array}{c}\text { D Helix } \\
\text { Setiap } \\
\text { Ujung } \\
{[\mathbf{m}]}\end{array}$ & $\begin{array}{c}\text { D Helix } \\
\text { Tengah } \\
{[\mathbf{m}]}\end{array}$ & $\begin{array}{c}\boldsymbol{n} \\
\text { Helix }\end{array}$ & $\begin{array}{c}\text { Beban } \\
{\left[\frac{\mathbf{k N}}{\mathbf{m}}\right]}\end{array}$ & $\begin{array}{c}\text { Luas } \\
\text { Area } \\
{\left[\mathbf{m}^{2}\right]}\end{array}$ & $\begin{array}{c}\boldsymbol{Q}_{\text {ult }} \\
{[\mathbf{k N}]}\end{array}$ \\
\hline 1 & 0,4 & 0,4 & 2 & 40.000 & 0,00785 & 212,596 \\
\hline 2 & 0,4 & 0,4 & 3 & 40.000 & 0,00785 & 236,817 \\
\hline 3 & 0,4 & 0,4 & 4 & 40.000 & 0,00785 & 251,605 \\
\hline 4 & 0,4 & 0,4 & 5 & 40.000 & 0,00785 & 253,260 \\
\hline 5 & 0,4 & 0,6 & 3 & 40.000 & 0,00785 & 254,403 \\
\hline 6 & 0,4 & 0,6 & 4 & 40.000 & 0,00785 & 282,281 \\
\hline 7 & 0,4 & 0,6 & 5 & 45.000 & 0,00785 & 296,960 \\
\hline
\end{tabular}

Hasil perhitungan nilai daya dukung ultimate dari setiap metode yang digunakan pada tanah lempung dan tanah pasir dapat dilihat pada Tabel 12.

Tabel 12. Rekapitulasi Hasil Daya Dukung Ultimate

\begin{tabular}{|c|c|c|c|c|c|c|}
\hline $\begin{array}{l}\text { Jenis } \\
\text { Tanah }\end{array}$ & $\begin{array}{c}\text { D Helix } \\
\text { Setiap } \\
\text { Ujung } \\
{[\mathrm{m}]}\end{array}$ & $\begin{array}{c}\text { D Helix } \\
\text { Tengah } \\
{[\mathrm{m}]}\end{array}$ & $\begin{array}{c}n \\
\text { Helix }\end{array}$ & $\begin{array}{c}Q_{\text {ult }} \text { Metode } \\
\text { Cylindrical } \\
\text { Shear }[\mathrm{kN}]\end{array}$ & $\begin{array}{c}Q_{\text {ult }} \text { Metode } \\
\text { Individual } \\
\text { Bearing }[\mathrm{kN}]\end{array}$ & $\begin{array}{c}Q_{\text {ult }} \text { Metode } \\
\text { Elemen } \\
\text { Hingga }[\mathrm{kN}]\end{array}$ \\
\hline \multirow{7}{*}{$\begin{array}{c}\text { Tanah } \\
\text { Lempung }\end{array}$} & 0,4 & 0,4 & 2 & 199,076 & 113,707 & 203,439 \\
\hline & 0,4 & 0,4 & 3 & 199,076 & 160,218 & 268,054 \\
\hline & 0,4 & 0,4 & 4 & 199,076 & 206,729 & 277,409 \\
\hline & 0,4 & 0,4 & 5 & 199,076 & 253,241 & 279,280 \\
\hline & 0,4 & 0,6 & 3 & 265,016 & 222,233 & 323,181 \\
\hline & 0,4 & 0,6 & 4 & 265,016 & 330,759 & 351,864 \\
\hline & 0,4 & 0,6 & 5 & 265,016 & 439,286 & 352,528 \\
\hline \multirow{7}{*}{$\begin{array}{l}\text { Tanah } \\
\text { Pasir }\end{array}$} & 0,4 & 0,4 & 2 & 610,150 & 698,147 & 212,596 \\
\hline & 0,4 & 0,4 & 3 & 610,150 & $1.031,438$ & 236,817 \\
\hline & 0,4 & 0,4 & 4 & 610,150 & $1.364,729$ & 251,605 \\
\hline & 0,4 & 0,4 & 5 & 610,150 & $1.698,021$ & 253,260 \\
\hline & 0,4 & 0,6 & 3 & 732,790 & $1.475,827$ & 254,403 \\
\hline & 0,4 & 0,6 & 4 & 732,790 & $2.253,506$ & 282,281 \\
\hline & 0,4 & 0,6 & 5 & 732,790 & $3.031,186$ & 296,960 \\
\hline
\end{tabular}

Tabel 13. Persentase Kenaikan Nilai Daya Dukung akibat Penambahan Jumlah Helix

\begin{tabular}{ccccc}
\hline $\begin{array}{c}\text { Jenis } \\
\text { Tanah }\end{array}$ & $\begin{array}{c}\text { Kenaikan } \\
\text { Jumlah Helix }\end{array}$ & $\begin{array}{c}\text { Metode } \\
\text { Cylindrical } \\
\text { Shear [\%] }\end{array}$ & $\begin{array}{c}\text { Metode } \\
\text { Individual } \\
\text { Bearing [\%] }\end{array}$ & $\begin{array}{c}\text { Metode } \\
\text { Elemen } \\
\text { Hingga [\%] }\end{array}$ \\
\cline { 2 - 5 } Tanah & 2 ke 3 & 0 & 29,03 & 24,11 \\
\cline { 2 - 5 } Lempung & 3 ke 4 & 0 & 22,50 & 3,37 \\
\cline { 2 - 5 } & 4 ke 5 & 0 & 18,37 & 0,67 \\
\hline \multirow{2}{*}{ Tanah Pasir } & Rata -rata & 0 & 23,30 & 9,38 \\
\cline { 2 - 5 } & 2 ke 3 & 0 & 32,31 & 10,23 \\
\cline { 2 - 5 } & 3 ke 4 & 0 & 24,42 & 5,88
\end{tabular}


Tabel 13. Persentase Kenaikan Nilai Daya Dukung akibat Penambahan Jumlah Helix Lanjutan

\begin{tabular}{|ccccc}
\hline Jenis Tanah & $\begin{array}{c}\text { Kenaikan } \\
\text { Jumlah Helix }\end{array}$ & $\begin{array}{c}\text { Metode } \\
\text { Cylindrical } \\
\text { Shear [\%] }\end{array}$ & $\begin{array}{c}\text { Metode } \\
\text { Individual } \\
\text { Bearing [\%] }\end{array}$ & $\begin{array}{c}\text { Metode Elemen } \\
\text { Hingga [\%] }\end{array}$ \\
\hline \multirow{2}{*}{ Tanah Pasir } & 4 ke 5 & 0 & 19,63 & 0,65 \\
\cline { 2 - 5 } & Rata -rata & 0 & 25,45 & 5,59 \\
\hline
\end{tabular}

Pada Tabel 13, dapat dilihat bahwa metode cylindrical shear tidak terjadi kenaikan kapasitas daya dukung akibat penambahan jumlah helix yang dilakukan baik pada tanah lempung dan tanah pasir. Pada metode individual bearing tanah lempung dan tanah pasir kenaikan kapasitas yang paling besar terjadi pada saat jumlah helix pada tiang helical ditambah yang semula memiliki 2 helix menjadi 3 helix kemudian pada penambahan jumlah helix yang selanjutnya juga terjadi peningkatan pada kapasitas daya dukung yang dihasilkan, tetapi peningkatan yang terjadi tidak sebesar sebelumnya. Pada metode elemen hingga, kenaikan kapasitas daya dukung yang cukup signifikan juga terjadi pada saat jumlah helix di tambah yang semula 2 helix menjadi 3 helix, sedangkan pada penambahan helix selanjutnya kenaikan kapasitas daya dukung yang dihasilkan sangatlah kecil. Nilai persentase rata-rata yang dihasilkan akibat penambahan jumlah helix pada tanah lempung adalah $9,38 \%$ dan pada tanah pasir sebesar $5,59 \%$.

Tabel 14. Persentase Kenaikan Nilai Daya Dukung akibat Penambahan Ukuran Diameter Helix Tengah Sebesar $20 \mathrm{~cm}$

\begin{tabular}{rcccc}
$\begin{array}{c}\text { Jenis } \\
\text { Tanah }\end{array}$ & $\boldsymbol{n}$ Helix & $\begin{array}{c}\text { Metode } \\
\text { Cylindrical } \\
\text { Shear [\%] }\end{array}$ & $\begin{array}{c}\text { Metode } \\
\text { Individual } \\
\text { Bearing [\%] }\end{array}$ & $\begin{array}{c}\text { Metode } \\
\text { Elemen } \\
\text { Hingga [\%] }\end{array}$ \\
\hline \multirow{3}{*}{$\begin{array}{c}\text { Tanah } \\
\text { Lempung }\end{array}$} & 3 & 24,88 & 27,91 & 17,06 \\
\cline { 2 - 5 } & 4 & 24,88 & 37,50 & 21,16 \\
\cline { 2 - 5 } & 5 & 24,88 & 42,35 & 20,78 \\
\hline \multirow{3}{*}{ Ranah Pasir } & Rata -rata & 24,88 & 35,92 & 19,67 \\
\cline { 2 - 5 } & 3 & 16,74 & 30,11 & 6,91 \\
\cline { 2 - 5 } & 4 & 16,74 & 39,44 & 10,87 \\
\cline { 2 - 5 } & 5 & 16,74 & 43,98 & 14,72 \\
\hline
\end{tabular}

Pada Tabel 14 metode cylindrical shear di tanah lempung dan pasir kenaikan nilai daya dukung akibat penambahan ukuran diameter tengah sebesar $50 \%$ nilainya sama karena pada metode cylindrical shear daya dukung yang dihasilkan dari jumlah helix yang berbeda memiliki daya dukung yang sama. Pada metode individual bearing persentase yang dihasilkan ketika jumlah helix ditambah maka persentase kenaikan daya dukungnya juga semakin meningkat, hal ini disebabkan pengaruh penambahan ukuran diameter helix yang cukup besar. Pada metode elemen hingga pengaruh kenaikan diameter terbesar terjadi pada saat ada 4 buah helix di tanah lempung dan nilai rata-rata yang dihasilkan akibat penambahan ukuran diameter tengah sebesar $50 \%$ adalah $19,67 \%$ sedangkan pada tanah pasir sebesar $10,83 \%$. 


\section{KESIMPULAN}

Berdasarkan hasil perhitungan analisis daya dukung menggunakan metode cylindrical shear, individual bearing, dan elemen hingga maka diperoleh kesimpulan sebagai berikut:

1. Penambahan jumlah helix pada tiang helical menambah kapasitas daya dukung sebesar 9,382\% pada tanah lempung dan $5,586 \%$ pada tanah pasir.

2. Penambahan ukuran diameter sebesar $50 \%$ meningkatkan kapasitas fondasi sebesar $19,66 \%$ pada tanah lempung dan $10,83 \%$ pada tanah pasir.

3. Terdapat perbedaan hasil daya dukung antara metode cylindrical shear dan individual bearing Karena pada metode cylindrical shear dari ujung helix paling atas sampai helix paling bawah dianggap menghasilkan satu daya dukung silinder saja dimana helix yang berada di tengah tidak berpengaruh dan menambah daya dukung, sedangkan pada metode individual bearing masing-masing helix yang berada pada tiang helical menghasilkan daya dukung sendiri.

4. Pada tanah lempung hasil analisis daya dukung dengan metode cylindrical shear lebih mendekati hasil dari metode elemen hingga, sedangkan pada tanah pasir metode cylindrical shear maupun individual bearing hasil daya dukung yang didapat kurang relevan dengan daya dukung yang dihasilkan oleh metode elemen hingga.

5. Metode individual bearing lebih cocok digunakan pada tiang helical yang memiliki jumlah helix sebanyak 3, 4, dan 5 karena nilai daya dukung ultimate yang dihasilkan cenderung sama dengan nilai daya dukung dari metode elemen hingga. Pada tiang yang memiliki 2 helix, metode ini kurang cocok untuk digunakan karena jarak antar helix yang terlalu jauh sehingga ada daya dukung selimut tiang yang seharusnya ada tetapi tidak diperhitungkan.

6. Metode cylindrical shear kurang cocok apabila jarak antar helix terlalu jauh. Metode ini lebih cocok pada tiang helical yang memiliki banyak helix dan dengan jarak antar helix yang lebih dekat.

\section{DAFTAR RUJUKAN}

Aryanata, A., \& Hamdhan, I. N. (2015). Analisis Daya Dukung Helical Pile Menggunakan Metode Elemen Hingga. Reka Racana, 20 (10), 2-6.

Barbour, S. L., Batrhurst, R. J., Boone, S., Brachman, R. W., Brockbank, B., Diederichs, M., Shang, J. (2006). Canadian Foundation Engineering Manual $4^{\text {th }}$ Edition. Fredericton: Canadian Geotechnical Society.

PLAXIS 2D Reference Manual. (2016). 